\title{
Market-Scanning Capability - A Scale to Measure Firms' Ability to Sense or Respond to the Changes in the Marketplace
}

\author{
M. Shahedul Alam ${ }^{1}$, Paul D. Guild ${ }^{2} \&$ Douglas I. Sparkes ${ }^{3}$ \\ ${ }^{1}$ MPA Program, Royal Military College of Canada, Kingston, ON, Canada \\ ${ }^{2}$ Management Sciences Department, University of Waterloo, ON, Canada \\ ${ }^{3}$ MBET Program, Conrad Centre for Business, Entrepreneurship \& Technology, Waterloo, ON, Canada \\ Correspondence: M. Shahedul Alam, MPA Program, Royal Military College of Canada, Kingston, ON, Canada. \\ E-mail: shahedul.alam@rmc.ca
}

Received: August 29, 2012 Accepted: December 24, 2012 Online Published: January 16, 2013

doi:10.5539/ijbm.v8n4p10

URL: http://dx.doi.org/10.5539/ijbm.v8n4p10

\begin{abstract}
A new construct called market-scanning capability has been conceptualized that captures firms' capability to sense or to respond to the changes in the marketplace. The second-order reflective construct was found to have four first-order components that are named as CustInfo (i.e., collection of information about customers), CmpInfo (i.e., information regarding competitiveness), MktResp (i.e., responsiveness to collected market-related information) and Coord (i.e., coordination among different business units of the firm). The first-order components of market-scanning capability construct provide a theoretical understanding useful to the practitioners who want to design the business processes to revamp the market-scanning capability of their organizations.
\end{abstract}

Keywords: environmental scanning, market scanning, capability, sense-and-respond framework

\section{Introduction}

In a dynamic business environment, the existing opportunities may disappear causing firms to loose the competitive advantages they once had - even though their static resources did not change. Hence, when the business environment is changing, resource-based view of the firm is insufficient to explain how firms gain and sustain competitive advantages. Wiggins and Ruefli (2002; 2005), drawing on the works of Schumpeter (1939; 1942) and D'Aveni (1994), explained how hyper-competition diminishes competitive advantage among firms. Due to rapid changes in the business environment, firms are finding it increasingly difficult to retain for a longer time their strategic advantages over their competitors. Hence, sustainable competitive advantage is increasingly becoming dependent on the firms' ability to create a series of advantages over time (Wiggins and Ruefli 2005). In other words: firms that are operating in business environments characterized by high 'clock-speed' (Fine 1998), develop capabilities that enable them to create a series of temporary advantages which, in turn, help sustain competitive advantages over time (D’Aveni 1994; Brown and Eisenhardt 1998). In pursuit of identifying and benefiting from these temporary advantages on a continuous basis, firms have to develop information collecting and processing capabilities to sense the changing business environment and to find tangible ways to respond to those changes.

Haeckel (1999) proposed that enterprises operating in dynamic environments have to be adaptive and suggested that the success of these firms can be explained by a 'sense-and-respond' framework. This framework emphasizes firms' need to understand the changes in their business environment and provides a specific guideline regarding how to remain viable in the context of their evolving business environment. Firms using this framework invest in early detection of 'weak signals' (Ansoff 1975) to broaden their 'peripheral vision' (Day and Schoemaker 2006, Haeckel 2004). The sense-and-respond framework provides a firm its business context, helps its leaders to define reason for being, governing principles and high-level structure of the business (Haeckel 2000). A sense-and-respond mindset enable managers to identify weak signals what may first appear to be random noise, to 'imagine' these signals into a sense-making pattern, and to make decisions to respond to these changes that are happening in the business environment. In this context, a capability that firms need to sustain their competitive advantage is the ability to sense the changing nature of their business environment so that they can take steps to monetize the expected changes. Market-Scanning Capability (MktScan) makes firms aware of 
market opportunities - both explicit and tacit - within the industries in which they operate. MktScan capability also facilitates finding of new opportunities beyond the market segments that are currently on focus.

While all firms need to scan their business environment, a high level of scanning capability in market domain may be more necessary for firms in dynamic industries; since they often experience high intensity change (Cetron and Davies 2001; Day and Schoemaker 2004) and high uncertainties. Fast changing trends in development techniques and technology, customer preference and other environmental factors can deprive a firm of its current leading market position, allowing others, which place priority on innovation, to take the lead. One such example is Wang Computer, which "led the word processing industry in the early 1980s before Apple and IBM introduced PCs with word processing software... Wang could not see how PCs offered customer value. As a result, Wang's sales dropped and it went bankrupt" (Cohan and Unger 2006). To avoid such outcomes, firms need to search for and effectively use the latest information when innovating new products and services, enabling them to achieve sustainable competitive advantage (Han et al. 1998).

More market-oriented firms perform better than their less market-oriented counterparts (Narver and Slater 1990; Ruekert 1992; Deshpande et al. 1993; Jaworski and Kohli 1993; Slater and Narver 1994; Atuahene-Gima 1995; Pelham and Wilson 1996; Pitt et al. 1996). Firms with a high degree of market-scanning activities have an improved capability to process information that relates to the changes in customer choice, significantly reducing demand uncertainty for their products and services; i.e. these firms have a better idea about 'what needs to be done'. Firms explore ideas for new products and services to meet identified and unexpressed customer needs (e.g., 'lead users' in von Hippel, 1988).

\section{A Measurement Scale for Market-Scanning Capability (MktScan)}

Although a scale for market-scanning capability did not exist, several scales to measure the market orientation of a firm have been proposed and discussed in the literature. The relevant items from various market orientation scales were used to develop a new scale for market-scanning capability. Kohli and Jaworski (1990) used the MARKOR scale and Narver and Slater (1990) proposed the MKTOR scale to measure market orientation. Kohli and Jaworski (1990) described market orientation as "the organization-wide generation of market intelligence pertaining to current and future customer needs, dissemination of the intelligence across departments, and organization-wide responsiveness to it". According to Narver and Slater (1990), market orientation comprises three behavioral components - customer orientation, competitor orientation and inter-functional co-ordination. They also described market orientation as an "organizational culture that effectively and efficiently creates" these behaviors. Han et al. (1998) used a combination of the existing scales from the literature, primarily influenced by Narver and Slater (1990), when examining the role of innovation in the relationship between market orientation and performance. Also, Narver et al. (2004) described two separate scales to measure the market orientation of a firm - proactive market orientation and reactive market orientation. In order to identify the items for a scale to measure firm-level market-scanning capability (MktScan) of firms, the following three market orientation scales were used: the market orientation scale proposed by Narver and Slater (1990), proactive market orientation scale proposed by Narver et al. (2004) and reactive market orientation scale used by Narver et al. (2004). An online survey was conducted as part of a larger project that included 17 items taken from the above-mentioned scales of market orientation. Only items that were closer to the 'face-validity' of market-scanning capability were considered as potential items for the scale.

\section{Data Collection}

The resulting survey instrument was delivered through the web to a national sample of manufacturing firm managers in Canada. A web-based survey was selected as a methodological option because of the benefits of speed, reasonable cost, and easy accessibility, and because of the geographic dispersion of the target participants (Ilieva et al. 2002; Deutskens et al. 2004; Cole 2005; Evans and Mathur 2005; Deutskens et al. 2006; Deutskens et al. 2006). When the contact email information of C-level officers (e.g., CEO, CTO) was not available, preference was given to recruit someone from Marketing, General Management, or R\&D departments.

The Industry Canada database of Canadian Company Capabilities (CCC 2008) was used to find contact information of Canadian companies who are engaged primarily in manufacturing. A total of 17,272 usable contacts (i.e., email addresses) for firms who listed their primary business activity as 'Manufacturer / Processor / Producer' were available. These firms were invited through email to participate in a web-based survey. The contact rate for the survey was $77.3 \%$, while the cooperation rate was $3.1 \%$. With an initial count of responses of 476 cases (which included those responses that had some missing values), the response rate was $2.8 \%$. A few other contacts attempted to take the survey, but their responses did not include enough data points; therefore these cases were discarded by the Survey Research Centre at the University of Waterloo (SRC at uWaterloo), 
that conducted the survey. Every effort was made to increase the response rate by development of a user-friendly interface, by careful design of the questionnaire so that the questions were unambiguous, and by use of reminders. Also, the service of SRC at uWaterloo was used to conduct the survey with the expectation that the reputation of the university would help increase the response rate. The main body of the survey consisted of a list of 7-point Likert scale questions. The survey also asked questions about profiles of the business and about characteristics of the individual respondents within the business.

\subsection{Remedies for Possible Systemic Bias in Survey Data}

Podsakoff et al. (2003) defined social desirability as "tendency on the part of individuals to present themselves in a favorable light, regardless of their true feelings about an issue or a topic." This view arises from people's need for perceived social acceptance and their belief that such an acceptance can be attained by means of culturally acceptable and appropriate behavior (Crowne and Marlowe 1964). According to Ganster et al. (1983), social desirability may suppress a true relationship, serve as a moderator for a relationship between two other constructs, or, at least, can change the strength of a relationship. Each of the questions in the survey instrument was examined and improved to avoid social desirability bias. Anonymity reduces the common method variances caused by social desirability of the respondents. The design and delivery method of the survey ensured anonymity, and respondents were aware of the fact that their responses were anonymous.

When respondents let their personal feelings and knowledge influence their rating of a particular item or person, the resulting bias has been defined as leniency bias (Guilford 1954; Schriesheim et al. 1979; Farh and Dobbins 1989; Vinton and Wilke 2011). When raters are familiar with the ratee or the researchers who are conducting the survey, the familiarity might influence the responses. Selections of respondents who are unknown to the researcher and ensuring anonymity of the respondents in a web survey method usually help to avoid this kind of bias. The same approach was used in the present study by selecting respondents who did not have prior knowledge of the researchers.

People in general have a tendency to appear consistent and rational in their responses. Research suggesting that people try to maintain consistency between their cognition and attitudes supports this observation. When it comes to a survey, this inherent tendency leads people to search for similarities in the questions and make an effort to answer those consistently. This tendency of respondents is called consistency motif (Podsakoff and Organ 1986; Johns 1994; Schmitt 1994) or the consistency effect (Salancik and Pfeffer 1977). The tendency is particularly problematic when the survey questions ask for retrospective accounts of people's attitudes, perception and behaviors (Podsakoff et al. 2003). As part of research design, changing the order of the questions as they are presented to the respondents would minimize the bias caused by consistency motif. Hence the order of the questions was randomly changed for the current study to achieve this goal.

As in the tendency of people to be influenced by social desirability, sometimes it is a property of the items in a construct or a questionnaire that has a similar influence (Thomas and Kilmann 1975; Nederhof 1985). For this phenomenon of item social desirability, items with more social desirability could exhibit a stronger as opposed to the same correlation due to the underlying constructs that these were intended to measure. In order to reduce the potential for such bias, it is important to avoid sensitive wordings that might act as a cue for the respondents. The questions were carefully reviewed to avoid such biases for the current study.

The opinion of a respondent about the content of a specific item in a questionnaire is often influenced by the way it is presented. When items are presented in a complex or ambiguous way, the respondents are prone to develop their own idiosyncratic meaning for them (Podsakoff et al. 2003), thereby creating the possibility of respondents' own biased tendencies (e.g., social desirability, leniency) becoming more pronounced. This complexity of or ambiguity to the item could be introduced by the use of technical jargon or colloquialisms (Spector 1992), double-barreled questions (cf. Hinkin 1995), unfamiliar or infrequently used words (Peterson 2000), or words with multiple meanings (Peterson 2000). Careful consideration of the wording of the questionnaire can reduce this bias, as was done in several steps in the current study.

Measurement context may also be responsible for common method variances. When both independent and dependent variables are measured concurrently, the likelihood of sharing systemic co-variation among them increases (Podsakoff et al. 2003). Measurement context is also influenced by both the location and the medium of the survey. For example, the face-to-face interview method induces more socially desirable responses than computer administered surveys (Martin and Nagao 1989; Richman et al. 1999). Since the current study was administered through the web, with invitations sent through email addresses, it had the advantage of being impersonal, likely affected by less social desirability bias. Moreover, the popularity of broadband internet accessibility would enable a web-based survey to be taken by the respondents in a variety of situations, perhaps 
reducing some common method variances arising from the single-type of location (e.g., an office environment). Although it was not asked whether the respondents completed the survey in one sitting, it is plausible to expect that some of the respondents answered some of the questions in work environment while completing the remaining questions in a different physical setting.

\section{Analysis: Components of Market-Scanning Capability (MktScan) Scale}

Market-scanning capability scale was modeled as a reflective construct. Researchers have also suggested an alternate way to model constructs which are formative in nature. Formative indicators are observed variables that 'cause' the latent variable as opposed to 'being affected' by the latent variable as is the case of reflective indicators (Bollen 1989; Bollen 2002). The direction of causality between indicators and latent constructs are opposite in formative and reflective models (MacCallum and Browne 1993). Formative constructs are driven by theory, and the items that constitute the latent formative constructs are not necessarily correlated (1999). In the formative model, all the items are necessary parts of the constructs, so dropping an indicator may change the conceptual domain of the construct.

Compared with the characteristics mentioned for formative indicators, reflective constructs can be independently modeled without interaction with other constructs (Rossiter 2002). Hence, the results are more generalizable and can be compared across studies. Hence, reflective constructs are more commonly used by social science researchers (Bollen 2002). Diamantopoulos and Winklhofer (2001) asserted: "The choice between a formative and a reflective specification should primarily be based on theoretical considerations regarding the causal priority between the indicators and the latent variable involved." Considering the theoretical aspects of the construct, a reflective model for the market-scanning capability (MktScan) was chosen since the indicators of the construct can be interchangeable to some extent and dropping a single indicator should not alter the conceptual domain of the construct. Indicators of the construct are also expected to co-vary. Lastly, since a common nomological net can be found for the construct indicators while considering the individual items, a reflective model seemed appropriate.

\subsection{Factor Analysis of MktScan Items}

Factor analysis (FA) is closely aligned with the development of a new scale since factor analysis helps researchers to "understand the latent factors or constructs that account for the shared variance among items" (Worthington and Whittaker 2006). There are a number of FA techniques available for factor extraction, including principal-axis factoring, maximum likelihood, image factoring, alpha factoring, and un-weighted and generalized least squares. Among these, principle-axis factoring and maximum likelihood are two widely used techniques. While Gerbing and Hamilton (1996) asserted that these two techniques are equally effective, Gorsuch (1997) reminded that occasional problems are more likely with maximum-likelihood than with principle-axis factoring. For the current study, principle-axis factoring was used to extract the underlying factors for the MktScan scale.

Next, the choice of rotation method was considered; typically two types of rotation are used - orthogonal and oblique. When the set of factors underlying a given items-set are assumed to be or known to be uncorrelated, then orthogonal rotation is recommended. When such factors are assumed to be or known to be correlated, oblique rotation is used (Gorsuch 1983; Thompson 2004). For the MktScan scale, the underlying factors were expected to be correlated to some extent, and hence, oblique rotation was preferred. Worthington and Whittaker (2006) further suggested that even if a theoretical understanding might indicate an uncorrelated factor set, data might exhibit correlation, suggesting the use of oblique rotation. Loehlin (1998) further suggested that orthogonal rotation often over-estimated loadings of individual items, even when both types of rotation produce similar factor structures. An over-estimation in loadings, if that occurred, would likely cause retention of items even when they were unnecessary. All these observations lent support for the choice of oblique rotation.

For choosing the number of factors to retain, Kaiser (1958) and Cattell (1966) provided important guidelines. Both used Eigenvalues to determine which factors to retain and which ones to drop. Kaiser (1958) suggested that factors with Eigenvalues of less than 1 are potentially unstable, so those should be dropped. On the other hand, Cattell (1966) used relative values of Eigenvalues to perform a Scree-test and estimated the correct number of factors. Gerbing and Anderson (1988), Tinsley and Tinsley (1987), Floyd and Widaman (1995) and Costello and Osborne (2005) also used Scree-test, sometimes in combination with other procedures.

With the above-mentioned guidelines, a factor analysis was performed on the seventeen items listed in Table 1 using SPSS 16.0 with principal axis factoring and promax rotation. Worthington and Whittaker (2006) suggested: "Conceptual interpretability is the definitive factor-retention criterion. In the end, researchers should retain a factor only if they can interpret it in a meaningful way no matter how solid the evidence is for its retention based 
on the empirical criteria". At the end, factor analysis is a combination of empirical and subjective approaches to find a solution that makes sense. Four underlying factors were found which were also conceptually coherent and these four factors were CustInfo, CmpInfo, MktResp and Coord. Upon further analysis, one item was dropped resulting in MktScan scale of sixteen items with Cronbach's Alpha of 0.875. Table 1 shows the list of individual items as they correspond to the different factors, their item loadings, Cronbach's Alpha of the scale factors and cross-correlations among and between factor pairs. Following is a discussion on the naming of the four retained factors of market-scanning capability.

\subsubsection{CustInfo (Customer Information Collection)}

With six items, CustInfo factor measured firm's inclination to proactively understand its customers' present and future needs. These items measured the extent to which firms used lead users to better understand the needs of their potential customers, the extent to which firms had internal brainstorming to absorb and understand the needs of their current customers, the extent to which firms tried to extrapolate the available data to understand the nature of changes that might happen in the future and to the extent firms tried to find out about their customers' unexpressed needs. These six items correlated strongly with Cronbach's Alpha of 0.843 . This factor alone explained $32.166 \%$ of the variance of the MktScan scale.

\subsubsection{CmpInfo (Competitiveness Information)}

The CmpInfo factor explained $8.264 \%$ of the MktScan scale variance. The Cronbach's Alpha of this 3-item factor was 0.739 . It encapsulated the competitiveness aspect of the firms' market information collection and processing activities. The items measured whether firms view themselves as more customer oriented than their competitors. It also captured whether firms view themselves as better in understanding their own customers' needs compared to their competitors.

\subsubsection{MktResp (Responsiveness to Market Information)}

MktResp was a 3-item factor that measured the responsiveness of firms to the market information that they collected. This factor explained $2.939 \%$ of the variance with a Cronbach's Alpha of 0.676 . This factor examined whether firms respond to the market changes that might be initiated by one of their rivals. It looked at firms' organizational structure to examine whehter it is well positioned to serve target markets. Also, the factor takes into account whether it is high on the agenda of firms' top management as demonstrated in their regular visits to customer installations.

\subsubsection{Coord (Coordination)}

This 4-item factor measured coordination aspects of firms' market information collection and it explained $2.637 \%$ of the MktScan scale variance. Coordination within firms was reflected in sharing resources among business units, sharing of information and customer experiences among business units and involvement of top management in identifying important issues. Also, the factor examined whether different functional areas of a firm exchanged information about their success and failures with customers to make sure that no customer-related mistakes are repeated and to promote practices that led to making customers happier. The Cronbach's Alpha of the factor was 0.708 .

Table 1. Factor analysis of mktscan scale items $(\mathrm{N}=467, \alpha=0.875)$

\begin{tabular}{|c|c|c|}
\hline & & Names and Corresponding \\
\hline Items & $\begin{array}{l}\text { Item } \\
\text { Loadings }\end{array}$ & $\begin{array}{l}\text { Cronbach's Alpha, Eigenvalues, \% of } \\
\text { Variance Explained and Cross-Correlations }\end{array}$ \\
\hline $\begin{array}{l}\text { MktScan1: We help our customers anticipate } \\
\text { developments in their markets. }\end{array}$ & 0.590 & Factor 1: CustInfo \\
\hline $\begin{array}{l}\text { MktScan2: We continuously try to discover } \\
\text { additional needs of our customers of which they } \\
\text { are unaware. }\end{array}$ & 0.670 & $\begin{array}{l}\text { Cronbach's Alpha }=0.843 \\
\text { Eigenvalue }=5.998 \\
\% \text { of Variance Explained }=32.166\end{array}$ \\
\hline $\begin{array}{l}\text { MktScan3: We brainstorm on how customers } \\
\text { use our products and services. }\end{array}$ & 0.550 & Correlation with CmpInfo $=0.413$ \\
\hline $\begin{array}{l}\text { MktScan4: We search for opportunities in areas } \\
\text { where customers have a difficult time expressing } \\
\text { their needs. }\end{array}$ & 0.702 & $\begin{array}{l}\text { Correlation with MktResp }=0.476 \\
\text { Correlation with Coord }=0.579\end{array}$ \\
\hline
\end{tabular}


MktScan5: We work closely with lead users who try to recognize customer needs months or even years before the majority of the market may recognize them.

MktScan6: We extrapolate key trends to gain insight into what users in a current market will need in the future.

MktScan7: We constantly monitor our level of commitment and orientation to serving customer needs.

MktScan9: Our strategy for competitive advantage is based on our understanding of customers' needs.

MktScan10: We are more customer-focused than our competitors.

MktScan13: We respond rapidly to the competitive actions of our rivals.

MktScan14: Top managers from each of our business units regularly visit customers.

MktScan15: Business functions within our organization are integrated to serve the target market needs.

MktScan8: We freely communicate information about our successful and unsuccessful customer experiences across all business functions.

MktScan12: Our salespeople share information with each other about competitors.

MktScan16: Top management regularly discusses competitors' strengths and weaknesses.

MktScan17: We share resources among business units.

MktScan11: Data on customer satisfaction are disseminated at all levels in this business unit on a regular basis.
0.873

0.663

0.607

Factor 2: CmpInfo

Cronbach's Alpha $=0.739$

Eigenvalue $=1.923$

$0.544 \%$ of Variance Explained $=8.264$

Correlation with MktResp $=0.600$

Correlation with Coord $=0.548$

0.704

0.485

0.553

0.633

Factor 3: MktResp

Cronbach's Alpha $=0.676$

Eigenvalue $=1.049$

$\%$ of Variance Explained $=2.939$

Correlation with Coord $=0.585$

Factor 4: Coord

0.549 Cronbach's Alpha $=0.708$

Eigenvalue $=1.013$

$0.574 \%$ of Variance Explained $=2.637$

This item was dropped since the cross-loading less than .15 difference from item's highest factor loading

\section{Reliability and Validity of the Construct}

The market-scanning capability (MktScan) was modeled as a second-order reflective construct with four first order factors. According to Nunnally (1978), in order for a factor to be considered as having convergent validity and reliability, both of Cronbach's Alpha and Construct (Composite) Reliability scores have to be 0.7 or greater. All the measures of Cronbach's Alpha and Composite Reliability scores were found to be higher than the cut-off; except the Cronbach's Alpha of the first order factor MktResp (0.676) that fell short of these criteria, but came very close. Fornell and Larcker (1981) further provided guidelines by specifying the measure of Average Variance Extracted (AVE) value of greater than 0.5 in order for the measurement error associated with the construct to be outweighed by the variance extracted through its indicators. The corresponding factor loading, AVE, Cronbach's Alpha and Composite Reliability value are shown in Table 2.

Table 2. Details of the construct's internal consistency, convergent validity

\begin{tabular}{lccc}
\hline Construct and it's factors & Order of the Construct and Cronbach's Alpha & AVE & Composite Reliability \\
\hline MktScan & $\mathbf{2}^{\text {nd }}$ Order $(\mathbf{0 . 8 7 5})$ & $\mathbf{0 . 6 0 8}$ & $\mathbf{0 . 8 6 1}$ \\
CustInfo & $1^{\text {st }}$ Order $(0.843)$ & 0.553 & 0.881 \\
CmpInfo & $1^{\text {st }}$ Order $(0.739)$ & 0.651 & 0.848 \\
MktResp & $1^{\text {st }}$ Order $(0.676)$ & 0.616 & 0.828 \\
Coord & $1^{\text {st }}$ Order $(0.708)$ & 0.534 & 0.821 \\
\hline
\end{tabular}




\section{Implications and Conclusion}

Firms can use their MktScan capability to either sense a weak signal or respond to developments in their business environment. They can sense information from their market domain, giving them a better idea of their customers' changing needs and what their competitors are doing. Further, firms can also respond to information collected in other domains such as new technology or regulatory change.

Based on the findings reported, MktScan capability is a second-order construct with four first-order components: CustInfo (i.e., customer information collection), CmpInfo (i.e., information regarding competitiveness), MktResp (i.e., responsiveness to market-related information) and Coord (i.e., coordination among different business units of the firm). Not only does the model of market-scanning capability provide a useful benchmarking tool, its development provides useful insights into what practitioners may need to consider as they develop their firm's capabilities.

Lastly, a capability is useful when it assists in the delivery of a goal. The goal is achieved through a focused combination of processes, tools, knowledge, skills, and organization. This theoretical understanding of MktScan capability is helpful for practitioners to guide development of business processes and activities aimed at developing a market-scanning capability within their firms.

\section{References}

Ansoff, H. I. (1975). Managing Strategic Surprise by Response to Weak Signals. California Management Review, 18(2), 21-33. http://dx.doi.org/10.2307/41164635

Atuahene-Gima, K. (1995). An Exploratory Analysis of the Impact of Market Orientation on New Product Performance: A Contingency Approach. Journal of Product Innovation Management, 12(4), 275-293. http://dx.doi.org/10.1111/1540-5885.1240275

Baker, W. E., \& Sinkula, J. M. (2002). Market Orientation, Learning Orientation and Product Innovation: Delving into the Organization's Black Box. Journal of Market-Focused Management, 5(1), 5-23. http://dx.doi.org/10.1023/A:1012543911149

Bollen, K. (2002). Latent Variables in Psychology and the Social Sciences. Annual Review of Psychology, 53(1), 605-634. http://dx.doi.org/10.1146/annurev.psych.53.100901.135239

Bollen, K. A. (1989). A New Incremental Fit Index for General Structural Equation Models. Sociological Methods and Research, 17(3), 303-316. http://dx.doi.org/10.1177/0049124189017003004

Brown, S. L., \& Eisenhardt, K. M. (1998). Competing on the Edge: Strategy as Structured Chaos. Boston, MA: Harvard Business School Press.

Cattell, R. B. (1966). The Scree Test for the Number of Factors. Multivariate Behavioral Research, 1(2), 245-276. http://dx.doi.org/10.1207/s15327906mbr0102_10

CCC, I. C. (2008). Canadian Company Capabilities, Industry Canada. Retrieved from http://www.ic.gc.ca/app/ccc/srch/cccBscSrch.do?lang=eng\&prtl=1.

Cetron, M. J., \& Davies, O. (2001). Trends Now Changing the World: Technology, the Workplace, Management, and Institutions. The Futurist, 35(2), 27-42.

Churchill, J. G. A. (1979). A Paradigm for Developing Better Measures of Marketing Constructs. Journal of Marketing Research, 16(1), 64-73. http://dx.doi.org/10.2307/3150876

Cohan, P. S., \& Unger, B. (2006). Four Sources of Advantage. Business Strategy Review, 17(1), 9-14. http://dx.doi.org/10.1111/j.0955-6419.2006.00384.x

Cole, S. T. (2005). Comparing Mail and Web-Based Survey Distribution Methods: Results of Surveys to Leisure Travel Retailers. Journal of Travel Research, 43(4), 422-430. http://dx.doi.org/10.1177/0047287505274655

Costello, A. B., \& Osborne, J. W. (2005). Best Practices in Exploratory Factor Analysis - Four Recommendations for Getting the Most From Your Analysis. Practical Assessment, Research \& Evaluation, 10(7), 1-9.

Crowne, D., \& Marlowe, D. (1964). The Approval Motive: Studies in Evaluative Dependence. New York: Wiley.

D’Aveni, R. A. (1994). Hypercompetition: Managing the Dynamics of Strategic Maneuvering. New York: Simon $\&$ Schuster.

Day, G. S., \& Nedungadi, P. (1994). Managerial Representations of Competitive Advantage. Journal of Marketing, 58(2), 31-44. http://dx.doi.org/10.2307/1252267 
Day, G. S., \& Schoemaker, P. J. H. (2004). Driving Through the Fog: Managing at the Edge. Long Range Planning, 37(2), 127-142. http://dx.doi.org/10.1016/j.lrp.2004.01.004

Day, G. S., \& Schoemaker, P. J. H. (2006). Peripheral Vision: Seven Steps to Seeing Business Opportunities Sooner. Boston, MA: Harvard Business School Press.

Deshpande, R., Farley, J. U., \& Webster Jr., F. E. (1993). Corporate Culture, Customer Orientation, and Innovativeness in Japanese Firms - A Quadrad Analysis. Journal of Marketing, 57(1), 23-27. http://dx.doi.org/10.2307/1252055

Deutskens, E., De Ruyter, K., \& Wetzels, M. (2006). An Assessment of Equivalence Between Online and Mail Surveys in Service Research. Journal of Service Research, 8(4), 346-355. http://dx.doi.org/10.1177/1094670506286323

Deutskens, E., De Ruyter, K., Wetzels, M., \& Oosterveld, P. (2004). Response Rate and Response Quality of Internet-Based Surveys: An Experimental Study. Marketing Letters, 15(1), 21-36. http://dx.doi.org/10.1023/B:MARK.0000021968.86465.00

Deutskens, E., De Jong, A., De Ruyter, K., \& Wetzels, M. (2006). Comparing the Generalizability of Online and Mail Surveys in Cross-National Service Quality Research. Marketing Letters, 17(2), 119-136. http://dx.doi.org/10.1007/s11002-006-4950-8

DeVellis, R. F. (2003). Scale Development - Theory and Applications. Thousands Oaks, CA: Sage.

Diamantopoulos, A., \& Winklhofer, H. M. (2001). Index Construction with Formative Indicators: An Alternative to Scale Development. Journal of Marketing Research, 38(2), 269-277. http://dx.doi.org/10.1509/jmkr.38.2.269.18845

Evans, J. R., \& Mathur, A. (2005). The Value of Online Surveys. Internet Research, 15(2), 195-219. http://dx.doi.org/10.1108/10662240510590360

Farh, J. L., \& Dobbins, G. H. (1989). Effects of Self-Esteem on Leniency Bias in Self-Reports of Performance: A Structural Equation Model Analysis. Personnel Psychology, 42(4), 835-850. http://dx.doi.org/10.1111/j.1744-6570.1989.tb00677.x

Fine, C. H. (1998). Clockspeed. New York: Basic Books.

Floyd, F. J., \& Widaman, K. F. (1995). Factor Analysis in the Development and Refinement of Clinical $\begin{array}{lllll}\text { Assessment Instruments. } & \text { Psychological }\end{array}$ http://dx.doi.org/10.1037/1040-3590.7.3.286

Fornell, C., \& Larcker, D. F. (1981). Evaluating Structural Equation Models with Unobservable Variables and Measurement Error. Journal of Marketing Research, 18(1), 39-50. http://dx.doi.org/10.2307/3151312

Ganster, D. C., Hennessey, H. W., \& Luthans, F. (1983). Social Desirability Response Effects: Three Alternative Models. Academy of Management Journal, 26(2), 321-331. http://dx.doi.org/10.2307/255979

Gerbing, D. W., \& Anderson, J. C. (1988). An Updated Paradigm for Scale Development Incorporating Unidimensionality and Its Assessment. Journal of Marketing Research, 25(2), 186-192. http://dx.doi.org/10.2307/3172650

Gerbing, D. W., \& Hamilton, J. G. (1996). Viability of Exploratory Factor Analysis as a Precursor to Confirmatory Factor Analysis. Structural Equation Modeling, 3(1), 62-72. http://dx.doi.org/10.1080/10705519609540030

Gorsuch, R. L. (1983). Factor Analysis. Hillsdale, NJ: Lawrence Erlbaum.

Gorsuch, R. L. (1997). Exploratory Factor Analysis: Its Role in Item Analysis. Journal of Personality Assessment, 68(1), 532-560. http://dx.doi.org/10.1207/s15327752jpa6803_5

Guilford, J. P. (1954). Psychometric Methods. New York: McGraw-Hill.

Haeckel, S. H. (1999). Adaptive Enterprise: Creating and Leading Sense-and-Respond Organizations. Cambridge, MA: Harvard Business School Press.

Haeckel, S. H. (2000). The Premise and Promise of Sense and Respond. Somers, NY: IBM Corporation.

Haeckel, S. H. (2004). Peripheral Vision: Sensing and Acting on Weak Signals Making Meaning out of Apparent Noise: The Need for a New Managerial Framework. Long Range Planning, 37(2), 181-189. http://dx.doi.org/10.1016/j.lrp.2004.01.006

Han, J. K., Kim, N., \& Srivastava, R. K. (1998). Market Orientation and Organizational Performance: Is 
Innovation The Missing Link? Journal of Marketing, 62(4), 30-45. http://dx.doi.org/10.2307/1252285

Hinkin, T. R. (1995). A Review of Scale Development Practices in the Study of Organizations. Journal of Management, 21(5), 967-988. http://dx.doi.org/10.1177/014920639502100509

Huber, G. P. (1984). The Nature and Design of Post-Industrial Organizations. Management Science, 30(8), 928-951. http://dx.doi.org/10.1287/mnsc.30.8.928

Ilieva, J., Baron, S., \& Healey, N. M. (2002). Online Surveys in Marketing Research: Pros and Cons. International Journal of Market Research, 44(3), 361-379.

Jaworski, B. J., \& Kohli, A. K. (1993). Market Orientation - Antecedents and Consequences. Journal of Marketing, 57(3), 53-70. http://dx.doi.org/10.2307/1251854

Johns, G. (1994). How Often were You Absent - A Review of the Use of Self-Reported Absence Data. Journal of Applied Psychology, 79(4), 574-591. http://dx.doi.org/10.1037/0021-9010.79.4.574

Kaiser, H. F. (1958). The Varimax Criterion for Analytic Rotation in Factor Analysis. Psychometrika, 23(3), 187-200. http://dx.doi.org/10.1007/BF02289233

Kohli, A. K., \& Jaworski, B. J. (1990). Market Orientation: The Construct, Research Propositions, and Managerial Implications. Journal of Marketing, 54(2), 1-18. http://dx.doi.org/10.2307/1251866

Loehlin, J. C. (1998). Latent Variable Models: An Introduction to Factor, Path, and Structural Analysis. Mahwah, NJ: Lawrence Erlbaum.

MacCallum, R. C., \& Browne, M. W. (1993). The Use of Causal Indicators in Covariance Structure Models: Some Practical Issues. Psychological Bulletin, 114(3), 533-541. http://dx.doi.org/10.1037/0033-2909.114.3.533

Marsh, H. W., \& Hocevar, D. (1985). Application of Confirmatory Factor Analysis to the Study of Self-Concept: First- and Higher Order Factor Models and Their Invariance Across Groups. Psychological Bulletin, 97(3), 562-582. http://dx.doi.org/10.1037/0033-2909.97.3.562

Martin, C. L., \& Nagao, D. H. (1989). Some Effects of Computerized Interviewing on Job Applicant Responses. Journal of Applied Psychology, 74(1), 72-80. http://dx.doi.org/10.1037/0021-9010.74.1.72

Martin, P. Y., \& Turner, B. A. (1986). Grounded Theory and Organizational Research. Journal of Applied Behavioral Science, 22(2), 141-157. http://dx.doi.org/10.1177/002188638602200207

Narver, J. C., \& Slater, S. F. (1990). The Effect of a Market Orientation on Business Profitability. Journal of Marketing, 54(4), 20-35. http://dx.doi.org/10.2307/1251757

Narver, J. C., Slater, S. F., \& MacLachlan, D. L. (2004). Responsive and Proactive Market Orientation and New-Product Success. Journal of Product Innovation Management, 21(5), 334-347. http://dx.doi.org/10.1111/j.0737-6782.2004.00086.x

Nederhof, A. J. (1985). Methods of Coping with Social Desirability Bias: A Review. European Journal of Social Psychology, 15(3), 263-280. http://dx.doi.org/10.1002/ejsp.2420150303

Nunnally, J. C. 1978. Psychometric Theory. New York: McGraw-Hill.

Pelham, A., \& Wilson, D. (1996). A Longitudinal Study of the Impact of Market Structure, Firm Structure, Strategy, and Market Orientation Culture on Dimensions of Performance. Journal of the Academy of Marketing Science, 24(1), 27-43. http://dx.doi.org/10.1007/BF02893935

Peterson, R. A. (2000). Constructing Effective Questionnaires. Thousand Oaks, CA: Sage.

Pitt, L., Caruana, A., \& Berthon, P. R. (1996). Market Orientation and Business Performance: Some European Evidence. International Marketing Review, 13(1), 5-18. http://dx.doi.org/10.1108/02651339610111317

Podsakoff, P. M., Lee, J. Y., MacKenzie, S. B., \& Podsakoff, N. P. (2003). Common Method Biases in Behavioral Research: A Critical Review of the Literature and Recommended Remedies. Journal of Applied Psychology, 88(5), 879-903. http://dx.doi.org/10.1037/0021-9010.88.5.879

Podsakoff, P. M., \& Organ, D. W. (1986). Self-Reports in Organizational Research: Problems and Prospects. Journal of Management, 12(4), 69-82. http://dx.doi.org/10.1177/014920638601200408

Richman, W. L., Kiesler, S., Weisband, S., \& Drasgow, F. (1999). A Meta-Analytic Study of Social Desirability Distortion in Computer Administered Questionnaires, Traditional Questionnaires, and Interviews. Journal of Applied Psychology, 84(5), 754-775. http://dx.doi.org/10.1037/0021-9010.84.5.754

Rossiter, J. R. (2002). The C-OAR-SE Procedure for Scale Development in Marketing. International Journal of 
Research in Marketing, 19(4), 1-31. http://dx.doi.org/10.1016/S0167-8116(02)00097-6

Ruekert, R. W. (1992). Developing a Market Orientation: An Organizational Strategy Perspective. International Journal of Research in Marketing, 9(4), 225-245. http://dx.doi.org/10.1016/0167-8116(92)90019-H

Salancik, G. R., \& Pfeffer, J. (1977). An Examination of the Need-Satisfaction Models of Job Attitudes. Administrative Science Quarterly, 22(3), 427-456. http://dx.doi.org/10.2307/2392182

Schmitt, N. (1994). Method Bias: The Importance of Theory and Measurement. Journal of Organizational Behavior, 15(5), 393-398. http://dx.doi.org/10.1002/job.4030150504

Schriesheim, C. A., Kinicki, A. J., \& Schriesheim, J. F. (1979). The Effect of Leniency on Leader Behavior Descriptions. Organizational Behavior and Human Performance, 23(1), 1-29. http://dx.doi.org/10.1016/0030-5073(79)90042-4

Schumpeter, J. (1942). Capitalism, Socialism, and Democracy. New York: Harper.

Schumpeter, J. A. (1939). Business Cycles: A Theoretical, Historical, and Statistical Analysis of the Capitalist Process. New York: McGraw-Hill.

Slater, S. F., \& Narver, J. C. (1994). Does Competitive Environment Moderate the Market Orientation-Performance Relationship. Journal of Marketing, 58(1), 46-55. http://dx.doi.org/10.2307/1252250

Slater, S. F., \& Narver, J. C. (1995). Market Orientation and the Learning Organization. Journal of Marketing, 59(3), 63-74. http://dx.doi.org/10.2307/1252120

Spector, P. E. (1992). A Consideration of the Validity and Meaning of Self-Report Measures of Job Conditions, In C. L. Cooper and I. T. Robertson (Eds.), International review of industrial and organizational psychology, 7 , 123-151. New York: Wiley.

Spector, P. E. (1992). Summated Rating Scale Construction: An Introduction. Newbury Park, Califomia: Sage.

Thomas, K. W., \& Kilmann, R. H. (1975). The Social Desirability Variable in Organizational Research: An Alternative Explanation for Reported Findings. Academy of Management Journal, 18(4), 741-752. http://dx.doi.org/10.2307/255376

Thompson, B. (2004). Exploratory and Confirmatory Factor Analysis: Understanding Concepts and Applications. Washington, DC: American Psychological Association. http://dx.doi.org/10.1037/10694-000

Tinsley, H. E. A., \& Tinsley, D. J. (1987). Uses of Factor Analysis in Counseling Psychology Research. Journal of Counseling Psychology, 34(4), 414-424. http://dx.doi.org/10.1037/0022-0167.34.4.414

Vinton, L., \& Wilke, D. J. (2011). Leniency Bias in Evaluating Clinical Social Work Student Interns. Clinical Social Work Journal, 39(3), 288-295. http://dx.doi.org/10.1007/s10615-009-0221-5

Von Hippel, E. (1988). The Sources of Innovation. New York: Oxford University Press.

Wiggins, R. R., \& Ruefli, T. W. (2002). Sustained Competitive Advantage: Temporal Dynamics and the Incidence and Persistence of Superior Economic Performance. Organization Science, 13(1), 82-105.

Wiggins, R. R., \& Ruefli, T. W. (2005). Schumpeter's Ghost: Is Hypercompetition Making the Best of Time Shorter? Strategic Management Journal, 26(10), 887-911. http://dx.doi.org/10.1002/smj.492

Worthington, R. L., \& Whittaker, T. A. (2006). Scale Development Research: A Content Analysis and Recommendations for Best Practices. The Counseling Psychologist, 34(6), 806-838. http://dx.doi.org/10.1177/0011000006288127 